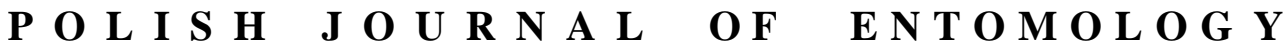

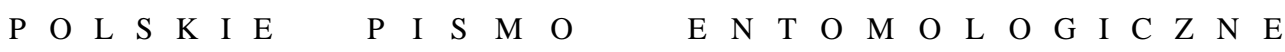

VOL. 83: 189-199

Lublin

30 September 2014

DOI: $10.2478 /$ pjen-2014-0014

\section{Trypoxylon kostylevi ANTROPOV, 1985 (Hymenoptera: Crabronidae) - a new species for Poland - and a key to Polish species of Trypoxylon LATREILLE, 1796}

\author{
PIOTR OLSZEWSKI, TADEUSZ PAWLIKOWSKI
}

Chair of Ecology and Biogeography, Nicolaus Copernicus University, Lwowska 1, 87-100 Toruń, Poland, e-mails: thecla@wp.pl, pawlik@biol.uni.torun.pl

\begin{abstract}
The paper presents the first information about the occurrence of Trypoxylon kostylevi ANTROPOV, 1985 in Poland on the basis of a female and a male collected from the Mazurian Lakeland. Brief characteristics of the species and its distribution in Europe are given. A key to the species of the genus Trypoxylon recorded in Poland is provided.
\end{abstract}

KEY WORDS: Hymenoptera, Crabronidae, Trypoxylon kostylevi, first faunistic record, Poland, determination key.

\section{INTRODUCTION}

The genus Trypoxylon LATREILLE, 1796 belongs to the family Crabronidae and the tribe Trypoxylini. A total of 634 species have been described so far, mostly from tropical and subtropical countries (PUŁAWSKI 2014). Only 16 species have been found in Europe, including 8 species in Poland (WIŚNIOWSKI 2004, BARBIER 2014). They are slender, medium-sized digger wasps with a body length ranging from 5.5 to $12 \mathrm{~mm}$. Species occurring in Europe are characterised by black pigmentation of the body and a petiolate abdomen (NOSKIEWICZ \& PUŁAWSKI 1960, JACOBS 2007). The internal edges of their eyes are indented and upwardly divergent. The wings have one submarginal cell and one discoidal cell.

Representatives of the genus Trypoxylon prefer forest habitats but also nest in other wet and dry habitats. In central Europe, females build their nests in hollow larval galleries in 
wood, lignified galls, loess escarpments and clay walls (OEHLKE 1970, LOMHOLDT 1984, BLÖSCH 2000, WIŚNIOWSKI 2003, WIŚNIOWSKI \& SZCZEPKO 2004, SZCZEPKO 2013). Adult insects feed on honeydew or nectar. They are often found on leaves of different plant species, but less frequently on inflorescences, where they search for food. Females prey on spiders (Aranea) to feed their larvae. Their parasitoids include Hymenoptera from the family of cuckoo wasps (Chrysididae), ichneumon wasps (Ichneumonidae) and Diptera from the family of flesh flies (Sarcophagidae) (BLÖSCH 2000).

Entomological research in the valley areas of northern Poland has yielded the first record of Trypoxylon kostylevi ANTROPOV, 1985 in Poland.

\section{MATERIAL AND METHODS}

The research was carried out in the Mazurian Lakeland in 2011-2013. The material is deposited in the collection of the first author. A Leica M205C microscope and camera were used for the photographic documentation. The identification key was compiled on the basis of material from the author's collection (P. OLSZEWSKI) of insects from Poland. Only the specimen of Trypoxylon kolazyi KOHL, 1893 was obtained from Bulgaria (leg. T. LJUBOMIROV).

\section{RESULTS}

During the research at Sierakowo (CD59), a female was caught on 7 July 2012 and a male on 6 August 2012 (leg. P. OLSZEWSKI) on a leaf of common lilac (Syringa vulgaris L.). The site encompasses a hill of sand and loam, covered with grassland vegetation supporting some segetal and ruderal species. It is also surrounded by arable fields and scattered buildings (Fig. 1).

The natural worth of this locality consists, among other things, in the occurrence of small pasque flowers Pulsatilla pratensis (L.) MILL, a rare, strictly protected species placed on the Red List of plants and fungi in Poland (ZARZYCKI \& SZELĄG 2006). Furthermore, the site is known for the occurrence of other interesting species of digger wasps: Miscophus ater LEPELETIER, 1845; Miscophus bicolor JURINE, 1807; Nysson dimidiatus JURINE, 1807, Tachysphex fulvitarsis (COSTA, 1867) and Tachysphex austriacus KOHL, 1892, relatively new to the fauna of Poland (OLSZEWSKI et al. 2013a, 2013b, 2013c, 2014). 


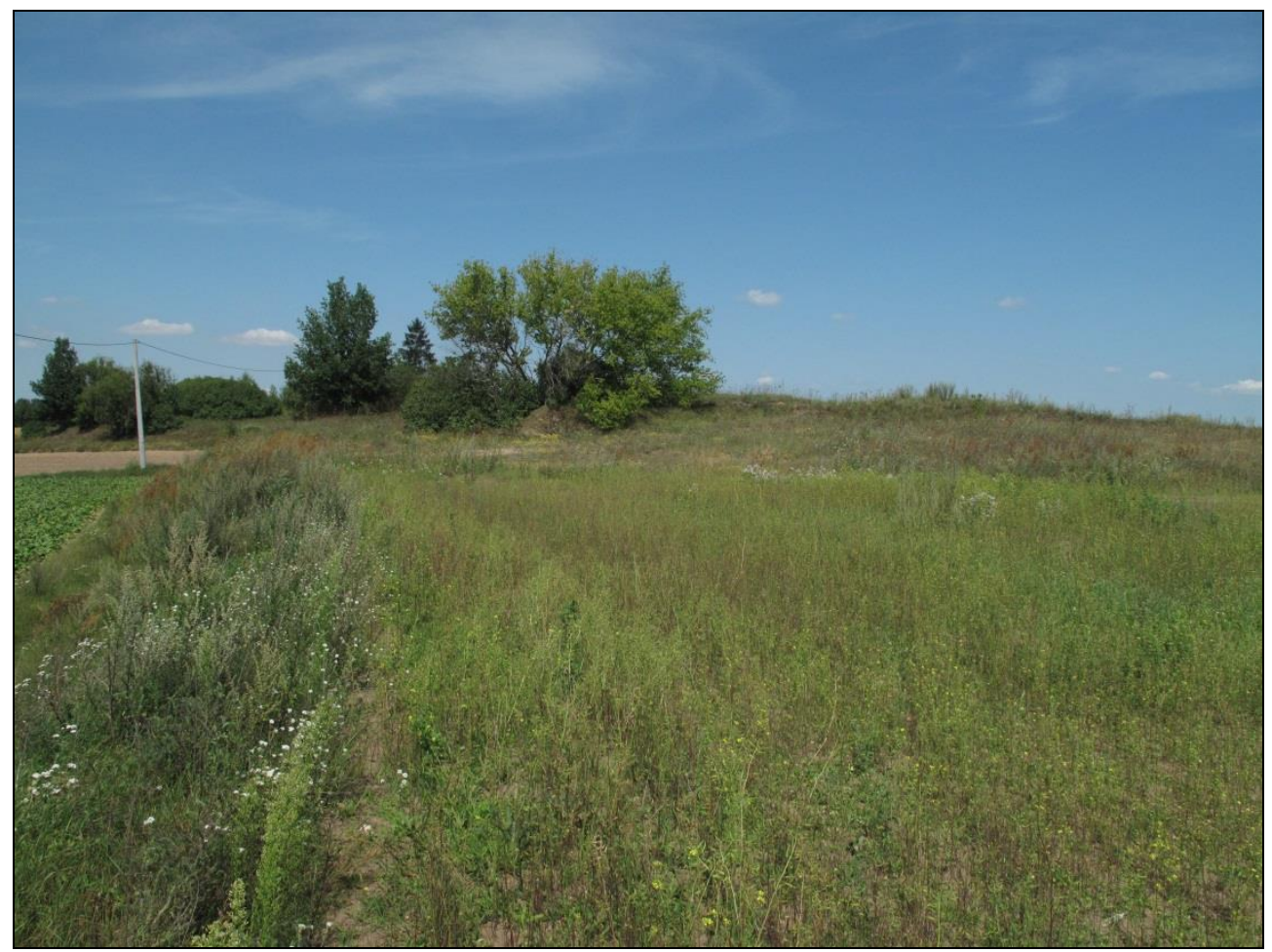

Fig. 1. Habitat of Trypoxylon kostylevi at Sierakowo (4 August 2012).

\section{DISCUSSION}

The species is known mainly from central and southern Europe (Fig. 2): Austria, Belgium, Bulgaria, the Czech Republic, Germany, Slovakia, Ukraine and Turkey (GuSEnleitner 1991, BAugnÉE 2003, GorobChishin 2006, JACOBS \& BURGER 2007, BAYINDIR et al. 2013).

It has probably been overlooked in many places in Europe because of its great similarity to $T$. clavicerum. The number of reports on the occurrence of $T$. kostylevi has increased significantly (JACOBS \& BURGER 2007, GUÉORGUIEV \& LJUBOMIROV 2009, SAURE 2010, TISCHENDORF et al. 2011, ZISKA \& SAURE 2011, BAYINDIR et al. 2013, SAURE 2013) since JACOBS (2007) defined and determined the traits of both species. According to JACOBS (2007), the diagonal striations of the propodeum in females occurs only at the base of the surface (Fig. 5D). The diagnostic traits in males are limited to the hamulus on the aedeagus in the endophallus (Fig. 6D). 


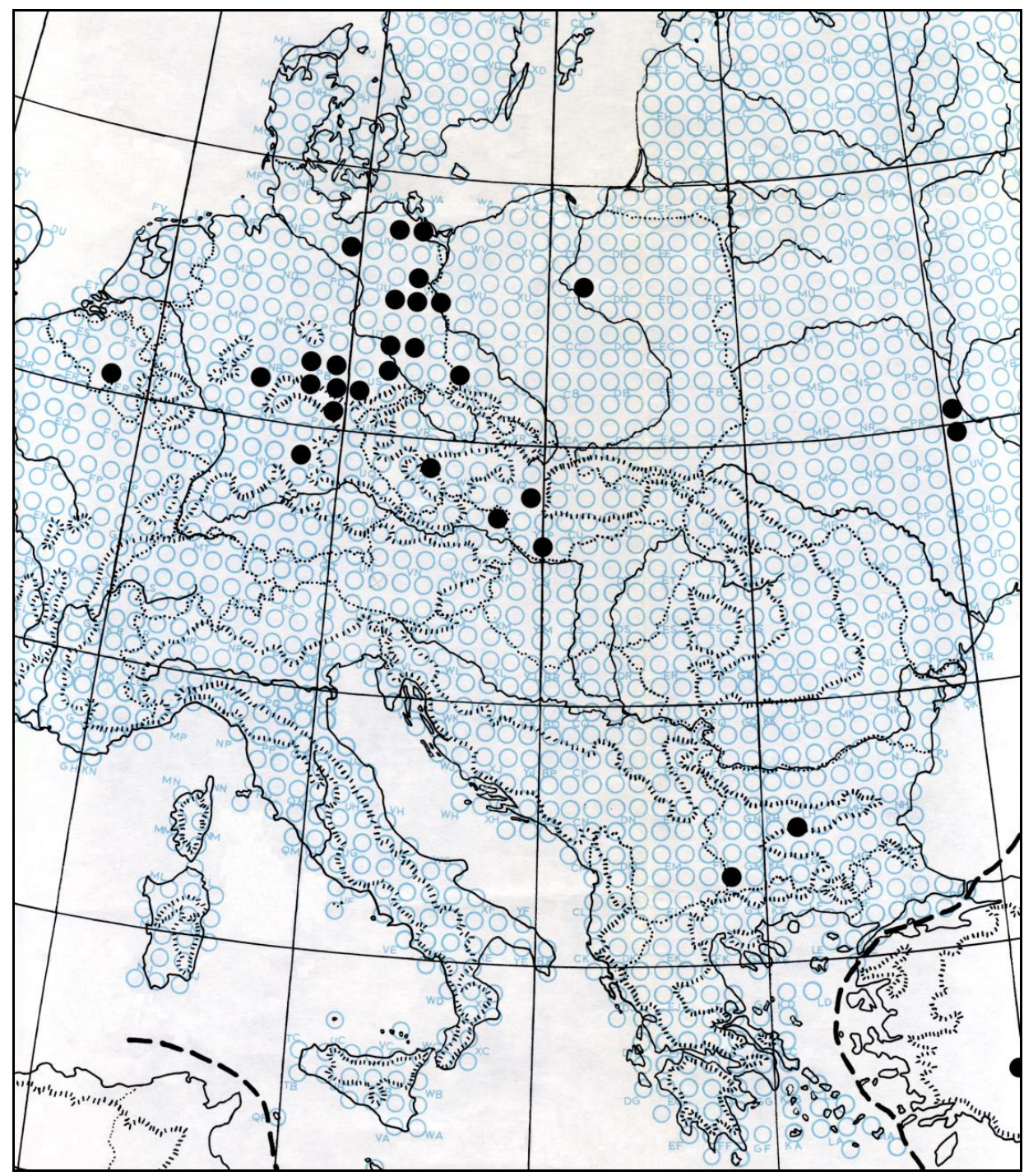

Fig. 2. Distribution of Trypoxylon kostylevi in Europe.

In the Polish identification key of NosKIEWICZ \& PUŁAWSKI (1960), the genus Trypoxylon comprises six species, including four known from Poland. Another paper by WIŚNIOWSKI \& SZCZEPKO (2004) provides additional data on the eight known species and two species that might be found, excluding T. kostylevi. Based on the aforementioned papers and the identification key of JACOBS (2007), the identification characteristics of all species known from Poland are listed below. 


\section{KEY TO POLISH SPECIES OF TRYPOXYLON}

1. Tibiae and tarsi of foreleg light-brown (Fig. 4C) $\ldots \ldots \ldots \ldots \ldots \ldots \ldots \ldots \ldots \ldots \ldots \ldots$

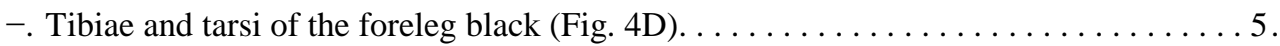

2. Anterior margin of clypeus medially with three or four small denticles (Fig. 3G). Distance between compound eyes on top of head 1.8-2.0 times greater than at clypeus. Frons with fine and scattered punctation. ............... T. kolazyi KoHL, 1893

-. Anterior margin of clypeus slightly elongated towards fore part with two denticles (Fig. 3F). Distance between compound eyes on top of head 1.2-1.5 times greater than at

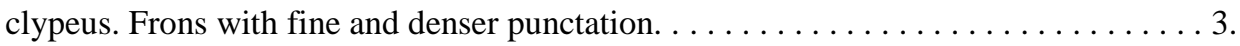

3. Oblique striation only at root of propodeum (Fig. 5D). Hamulus in males situated on top of aedeagus (Fig. 6D) . . . . . . . . . . . . . . . . . . Tostylevi ANTROPOV, 1985

-. Oblique striation covers almost entire propodeum surface (Fig. 5C). Hamulus in males situated below top of aedeagus (Fig. 6C).

T. clavicerum LEPELLETIER \& SERVILLE, 1828

5. Protrusion above base of antennae well developed, nearly at right angles to frons surface (Fig. 4A)......................... T. fronticorne GussAKOvsKIJ, 1936

-. Protrusion above base of antennae poorly developed, at an obtuse angle tofrons surface

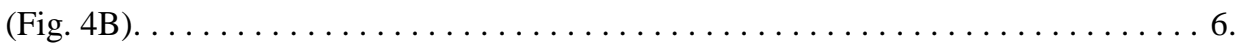

6. First tergite of metasoma as long as next two tergites together (Fig. 5A). Distance between compound eyes on top of head much greater than distance at clypeus. . . . . 7 .

-. First tergite of metasoma much shorter than the other two (Fig. 5B). Distance between compound eyes on top of head approximately equal to distance at clypeus. . . . . . 8 .

7. Lateral edges of clypeus straight or slightly convex (Fig. 3A). Endings of parameres in males shallowly indented (Fig. 6A)............... T. attenuatum SмIтH, 1851

-. Lateral edges of clypeus more or less concave (Fig. 3B). Endings of parameres in males deeply indented (Fig. 6B).................. T. deceptorium ANTROOPOV, 1991

8. Anterior edge of clypeus evenly concave (Fig. 3C). Length of last segment of antennae in males along longest edge 2.0-2.2 (exceptionally 2.4) times greater than its width at base. ... . . . . . . . . . . . . . . . . . . . . . . . . . . T. medium DE BEAUMONT, 1945

-. Anterior edge of clypeus straight or with small convexities on both sides (Fig. 3D). Length of last segment of antennae in males along longest edge 2.2-3.6 times greater

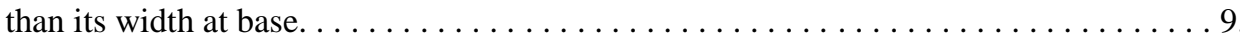

9. Mesonotum with small appendage at front between bases of fore coxae (Fig. 4E). Anterior part of clypeus with straight edge (Fig. 3E).... T. minus DE BEAUMONT, 1945

-. Mesonotum without appendix at front between bases of fore coxae (Fig. 4D). Anterior part of clypeus with small convexities (Fig. 3D)......... T. figulis (LinNAEUs, 1758) 

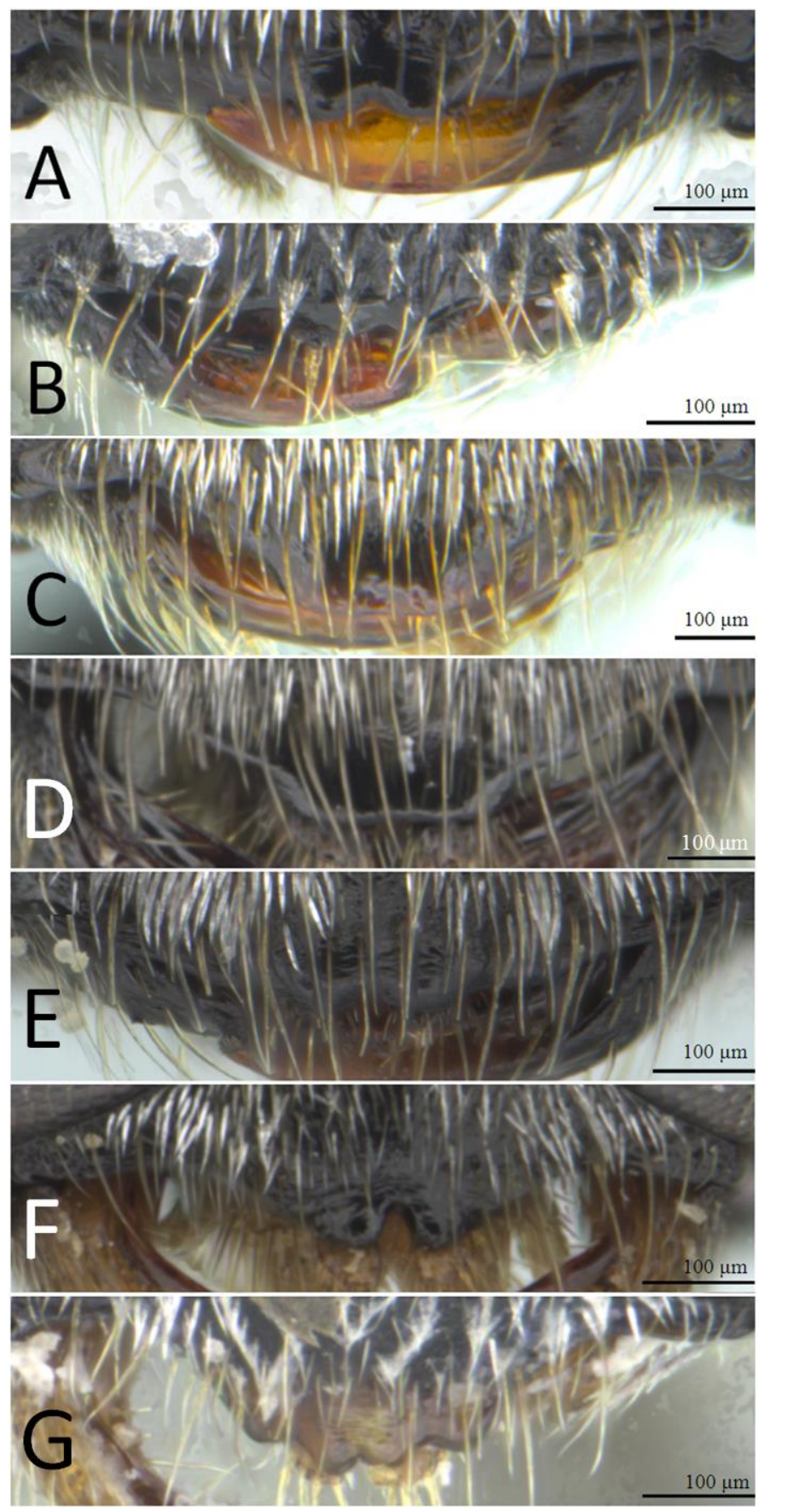

Fig. 3. The front part of the clypeus: A - Trypoxylon attenuatum, B $-T$. deceptorium, $\mathrm{C}-T$. medium, D - T. figulis, $\mathrm{E}-T$. minus, $\mathrm{F}-T$. clavicerum, $\mathrm{G}-T$. kolazyi. 

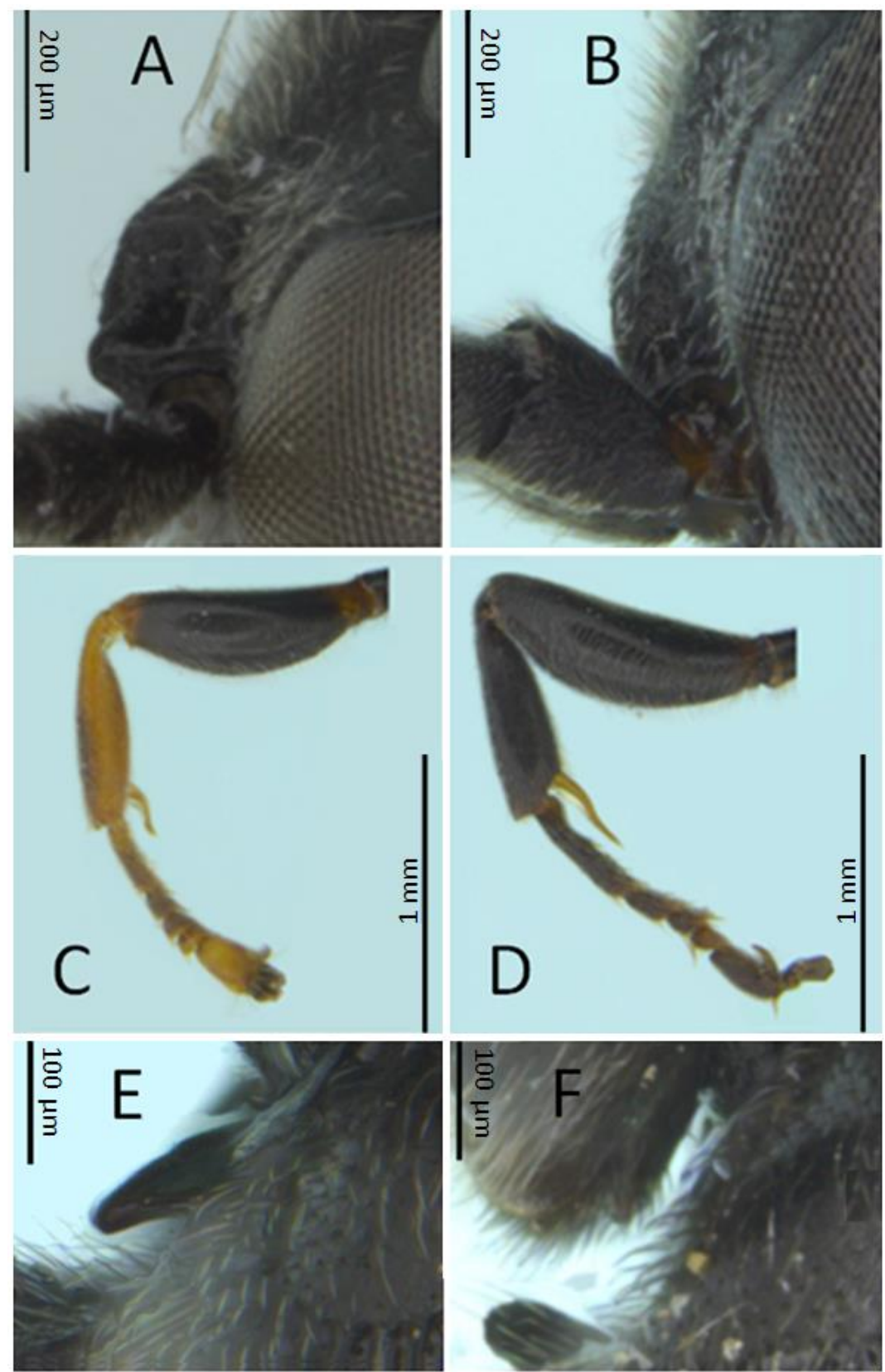

Fig. 4. A - protrusion above the base of the antennae of Trypoxylon fronticorne, side view, $\mathrm{B}$ - protrusion above the base of the antennae of T. minus, side view, $\mathrm{C}$ - first pair of legs of $T$. clavicerum, D - first pair ofl egs of T. minus, E - mesonotum at the front between the bases of the coxae of $T$ minus, side view, $\mathrm{F}$ - mesonotum at the front between the bases of the coxae of $T$. figulis, side view. 


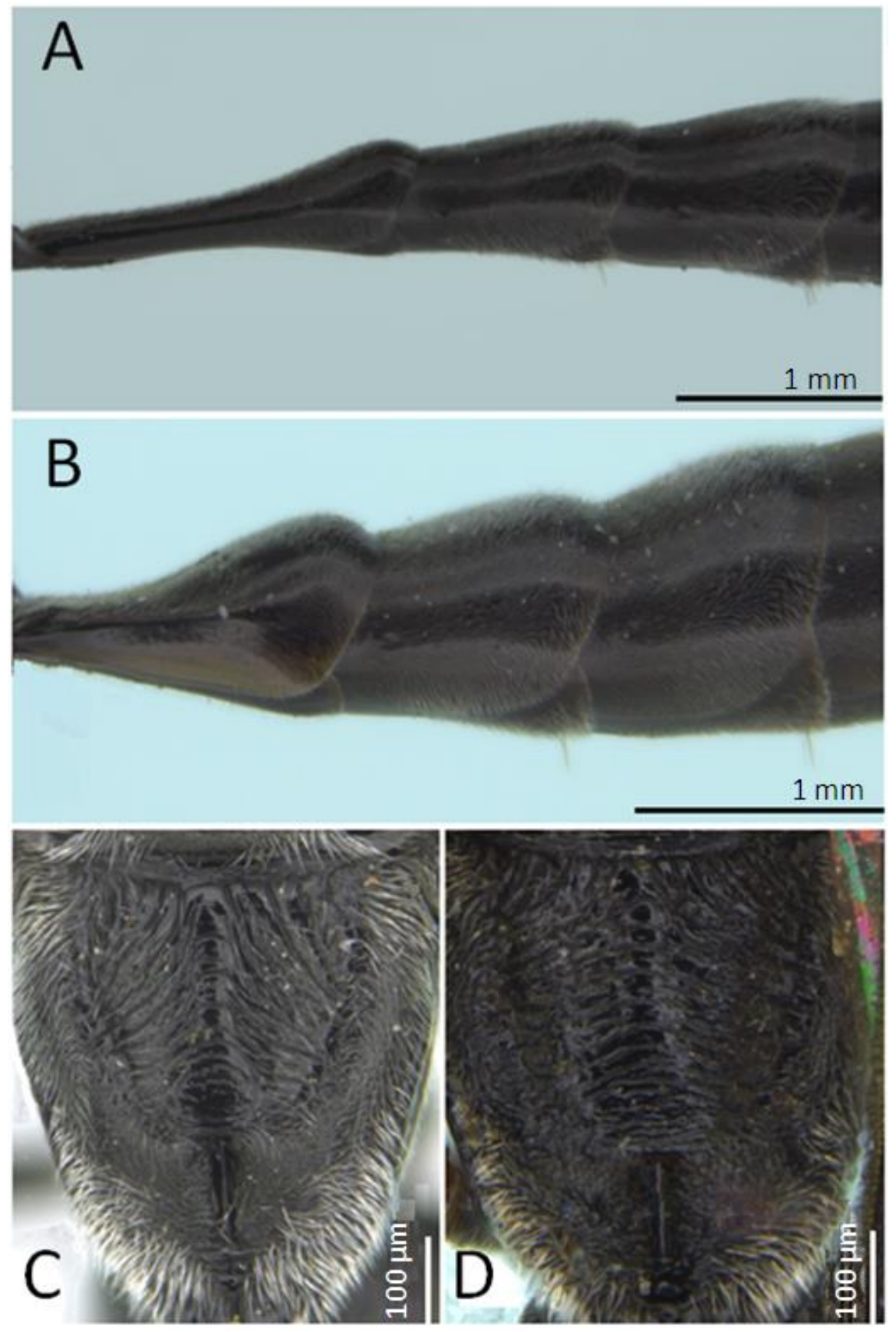

Fig. 5. A - first tergite of Trypoxylon attenuatum metasoma, side view, B - tergites of T. minus metasoma, side view, C - propodeum of $T$. clavicerum, dorsal view, $\mathrm{D}$ - propodeum of $T$. kostylevi, dorsal view. 

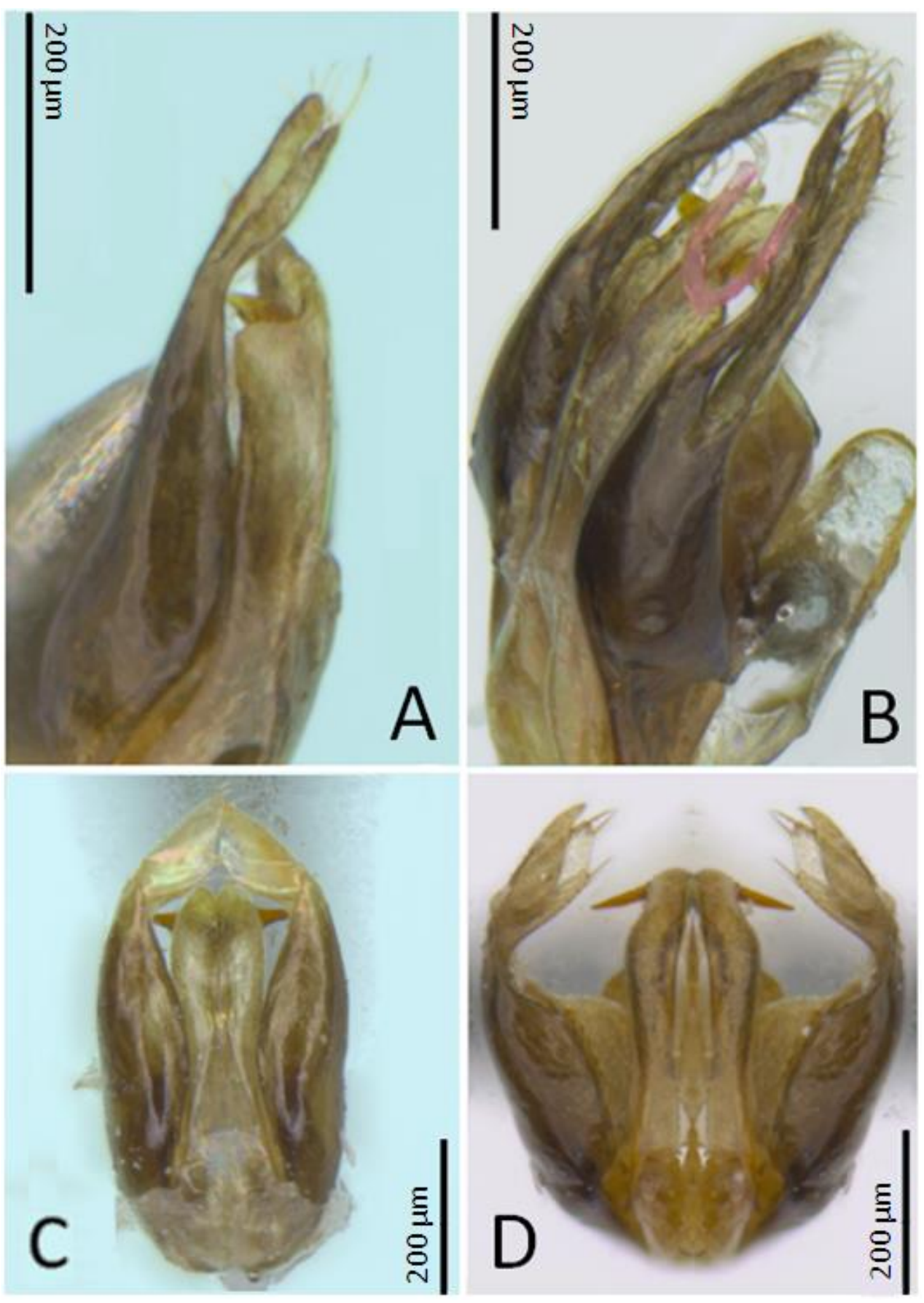

Fig. 5. Endophallus: A - Trypoxylon attenuatum, side view, B - T. deceptorium, side view, $\mathrm{C}-T$. clavicerum, front view, $\mathrm{D}-T$. kostylevi, front view. 


\section{ACKNOWLEDGEMENTS}

The authors thank Mr H.J. JACOBS (Senckenberg Deutsches Entomologisches Institut, Müncheberg, Germany) for confirming the identification of the specimens of T. kostylevi. We also owe a special a debt of gratitude to Prof. K. SzPILA (Nicolaus Copernicus University, Toruń) for his help with the preparation of the photos.

\section{REFERENCES}

BARBIER Y. 2014. Fauna Europaea: Trypoxylon. Fauna Europea version 1.0. Internet: http://www.faunaeur.org/

BAUgNÉE J.-Y. 2003. L'Hyménoptère Sphecidae Trypoxylon kostylevi en Belgique avec une note sur l'intérêtentomologique du vallon du Ri d'Hôwisse à Wavreille (province de Namur). Natura Mosana 56: 61-68.

BAYINDIR A., GÜRbÜz M.F., LjubOMirov T., Pohl D. 2013. Diversity of digger wasps in Kasnak Oak Forest Nature Reserve, Isparta, Turkey, with records of eight species new to Turkey (Hymenoptera: Sphecidae, Crabronidae and Ampulicidae). Zoology in the Middle East 59(2): $144-147$.

BLÖSCH M. 2000. Die Grabwespen Deutschlands. Goecke \& Evers, Keltern.

GoRobchishin V.A. 2006. Digger wasps (Hymenoptera: Sphecidae: Larrinae, Crabroninae, Mellininae, Nyssoninae, Philanthinae) of forest-steppes of Ukraine (fauna and ecology information). Pratsi Zoologichnogo Muzeyu Kyïvskogo Natsional'nogo Universytetu imeni Tarasa Shevchenka 4: 105-154. (in Ukrainian)

GuÉORguiev B.V., LubBomirov T. 2009. Coleoptera and Hymenoptera (Insecta) from Bulgarian section of Maleshevska Planina Mountain: study of an until recently unknown biodiversity. Acta Zoologica Bulgarica 61(3): 235-276.

GUSENLEITNER J. 1991. Neue und bemerkenswerte Grabwespenfunde für Österreich (Hymenoptera, Sphecidae). Linzer Biologische Beiträge 23: 643-648.

JACOBS H.J. 2007. Die Grabwespen Deutschlands. Ampulicidae, Sphecidae, Crabronidae. Goecke \& Evers, Keltern.

JACOBS H.J., Burger F. 2007. Trypoxylon kostylevi ANTROPOv, 1985 in Deutschland und Europa (Hymenoptera: Crabronidae). Bembix 24: 15-17.

Lomhold O. 1984. The Sphecidae (Hymenoptera) of Fennoscandia and Denmark. Fauna Entomologica Scandinavica 4(1): 1-224.

Noskiewicz J., PuŁawski W. 1960. Keys for the identification of Polish insects, Part XXIV, Hymenopterans Hymenoptera. Issue 67, Digger wasps Sphecidae. PWN, Warszawa. (in Polish)

OEHLKE J. 1970. Beiträge zur Insektenfauna der DDR: Hymenoptera Sphecidae. Beiträge zur Entomologie 20(7/8): 615-812. 
Olszewski P., Pawlikowski T., Piekarska-Boniecka H. 2013a. Nysson distinguendus Chevrier, 1867 (Hymenoptera: Crabronidae), a new species to the fauna of Poland. Fragmenta Faunistica 56(1): $43-46$.

Olszewski P., Wiśniowski B., PAwlikowski T., Straka J. 2013b. Tachysphex austriacus Kohl, 1892 (Hymenoptera: Crabronidae) in Poland. Wiadomości Entomologiczne 32(3): 202-206. (in Polish)

OlsZewski P., WiŚNiowski B., PAWLIKOwSKi T., SZPILA K. 2013c. New data about some rare species of aculeates (Hymenoptera: Aculeata) from Poland. Wiadomości Entomologiczne 32(2): 127 138. (in Polish)

OlsZewski P., WiŚNIOWSKi B., SZCZEPKO K. 2014. New data on the distribution of Miscophus JuRINE, 1807 species (Hymenoptera: Crabronidae) in Poland. Wiadomości Entomologiczne 33(1): 61-67. (in Polish)

PuŁawsKi W. 2014. Sphecidae sensu lato (=Apoidea excluding Apidae). Internet: http://research.calacademy.org/ent/catalog_sphecidae/

SAure C. 2010. Bienen und Wespen in den Gebieten Flughafen Tegel und Flughafensee in BerlinReinickendorf (Hymenoptera). Märkische Entomologische Nachrichten 12(2): 165-193.

SAURE C. 2013. Bienen und Wespen der Gosener Wiesen in Berlin, Bezirk Treptow-Köpenick (Hymenoptera). Märkische Entomologische Nachrichten 15(1): 1-54.

SzCZEPKO K. 2013. Ecology of sphecoid wasps (Hymenoptera, Apoidea, Spheciformes) of fallows in the Kampinowski National Park. Wydawnictwo Uniwersytetu Łódzkiego, Łódź. (in Polish)

Tischendorf S., Frommer U., Flugerl H.J. 2011. Kommentierte Rote Liste der Grabwespen Hessens (Hymenoptera: Crabronidae, Ampulicidae, Sphecidae) - Artenliste, Verbreitung, Gefährdung. Hessische Ministerium für Umwelt, Energie, Landwirtschaft und Verbraucherschutz, Wiesbaden.

WiŚNIOWSKI B. 2003. Superfamily. Vespoidea - wasps. [In:] DYLEWSKA M., WIŚNIOWSKI B. Stingers (Hymenoptera, Aculeata) of the Ojcowski National Park. Wydawnictwo Ojcowskiego Parku Narodowego, Ojców, 73-128. (in Polish)

WiŚnIOWSKI B. 2004. Annotated checklist of the Polish digger wasps (Hymenoptera: Sphecidae). Polskie Pismo Entomologiczne 73(1): 33-63.

WiŚNIOWSKI B., SZCZEPKO K. 2004. Trypoxylon fronticorne GuSSAKOVSKIJ - the species of digger wasp new for the Polish fauna. Wiadomości Entomologiczne 23(2): 89-96.

ZarZYCKI K., SzeląG Z. 2006. Red list of the vascular plants in Poland. [In:] MireK Z., ZarZYCKI K., Wojewoda W., Szeląg Z. (eds). Red list of plants and fungi in Poland. Instytut Botaniki im. W. Szafera Polskiej Akademii Nauk, Kraków 11-20. (in Polish)

ZiSka T., SAURe C. 2011. Ergebnisse der Untersuchungen zur Entomofauna im Berliner Teil des Tegeler Fließtales - Wespen und Bienen (Hymenoptera). Märkische Entomologische Nachrichten, Sonderheft 6: 103-122.

Received: 11 February 2014

Accepted: 8 May 2014 